\title{
اثر استراتيجية K.W.L في تنمية الوعي الصحي لاى طلبة كلية التربية الأساسية
}

م.د.سلمى لقتة ارهيف

م. محمد خليل إبراهيم

الفصل الأول: التعريف بالبحث:

$$
\text { مشكلة البحث: }
$$

يشهد تدريس العلوم في الوقت الحاضر المتسم بالتقدم العلمي والمعرفي تطوراً جذرياً،ولمواكبة هذا

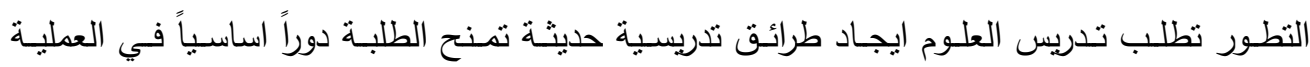
التعليمبة.

فقد اشارة العديد من البحوث والدراسات ضعف فاعلية الطرائق التدريسية التقليدية المنبعة في تدريس العلوم كونها تركز على المـادة العلميـة المتمثنل في حفظ الطلبـة للمعلومـات واسـترجاعها اكثر من

$$
\text { تركيزها على الطالب ونشاطه وتفكيره. }
$$

ولهذا اصبح التربويون بعتتون بالكيفية التي تمكن الطلبة من تحقيق تعلم افضل والى تغيير في طرائق التدريس التي يتبعها المعلم

وهذه كانت الومضة الأولى التي دفعت الباحثان للخوض في هذا البحث لأن أبناءنا وبناتتا رهينة بيد الطلبة المعلمين.

ثم بدأ الباحثان بالبحث والتقصي عن واقع مادة التربية الصحية التي تدرس في كلية التربية الأساسية لجميع الفروع وعند طرح بعض الأسئلة الخاصة بجانب من جوانب الوعي الصحي كانت الإجابة سلبية وأن المتعلمين يعتبرون المادة كتحصيل حاصل للنجاح فقط. ولا يستطيعون تطبيق ما تعلموه على أرض الواقع. 
وإن مـن الأسباب الأخـرى التي دعت الباحثنان للاهتمـام بهذه المشكلة هو تعقيد الحيـاة وظهور أمراض جديدة فتاكة نستدعي الجدية المطلقة في نشر الوعي الصحي بشكل منطقي وسلس كان يجب أن تكون البدايـة من المتعلمين المعلمون نزولاً إلى تلاميذهم في المدارس الابتدائية الذي فئي لفئي بات من الضروري توعيتهم منذ الصغر بالجانب الصحي ليستطيعوا تجنب الأمراض ويتحاشوها قدر المسنطاع.

ويعزو الباحثان سبب قلـة الاهنمـام بمـادة التربية الصـحية إلى إتبـاع التدريسبين الأسـاليب والطرائق التقليدية لاسيما وإنها مادة نظريـة بحتة تخلو من الجانب العملي وبذلك لا بـد من التفكير جديا في اختيار اسـاليب وطرائق تدريسية تجعل تعلم هذه المادة اكثر فاعلية وتعطي الطلبة الدور الايجابي في التعلم. لذلك اختار الباحثنان إستراتيجية الجدول الذاتي K.W.L وعلى حد علمه أنه لم

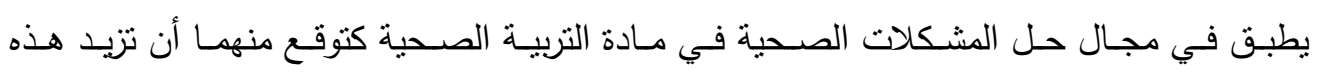
الاستراتيجية في التدريس من مقدرة المتعمين على زيادة الوعي الصحي لديهه. ويمكن تلخيص مشكلة البحث الحالي في السؤال الأتي: ما اثر إستراتيجية K.W.L في تتمية الوعي الصحي لدى طلبة كلية التربية الأساسية ؟ أهمية البحث:

إن العصـر الحـالي الذي نعيش فيـه اليوم هـو عصـر التقدم وازدهـار العلـم والتكنولوجيـا ويصـاحبه تطورات سريعة أدى إلى تغير مفهوم العلم بأنه مادة وطريقة ووسيلة لمواجهة المشكلات والتحديات التي يواجهها المجتمع. لذا تقع على عاتق التربويين مهمة كبرى في مواكبة خصائص العصر العلمي بهي وتفجر المعرفة العلمية، وأهم الوسـائل والطرق لمواجهة هذه التحديات هي التربيـة التي تمثل اللبنـة

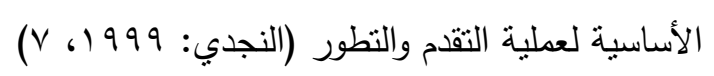

وقد أجمع المربون على أن معظم المشاكل التربوية ناشئـة في أساسها عن افتقار المدارس إلى المعلمين القديرين الذين هم روح المنهج ولا شيء في البيئة التربوية يستطيع أن يغني عن هذه الروح، وهم يتصلون اتصسالاً وثيقاً بتلاميذهم، وعليهم وعلى ما يتصفون بـه من خلق وعقيدة ومهارة 
ولباقة يتوقف نجاح عملية التربية، إضافة إلى أن هناك عناصر كثيرة يقوم عليها نجاح المعلم في

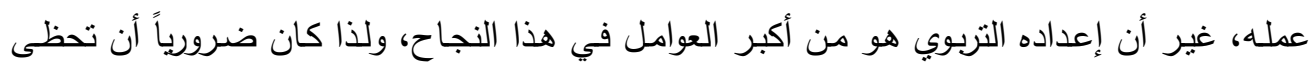

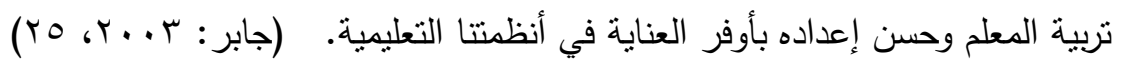

إن المعلم الناجح يجب أن ينقن عدة أنواع من طرائق التدريس إذا لم يكن كلها، حتى يستخدم المناسب منها حسب الموضوع وطبيعة المتعلمين. وتوصف طريقة التدريس المستخدمة بأنها

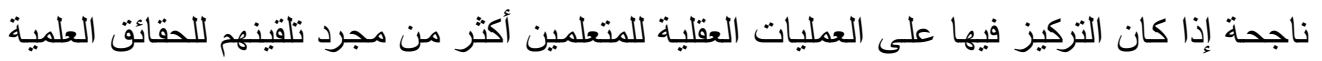

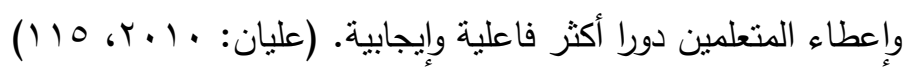

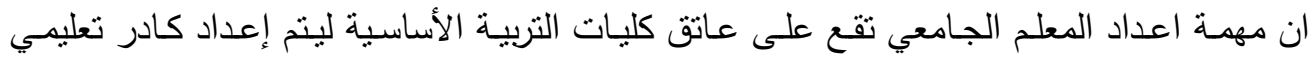

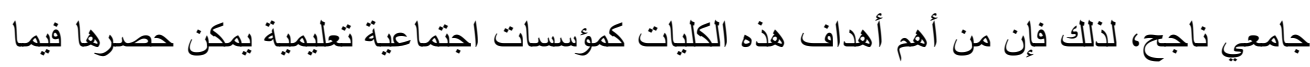
يلي:-

1- اعداد معلمين ذوي اهداف وقيم سـامية مؤهلين لأداء رسالتهم التربويـة والمهنيـة والعلميـة

والوطنية لبناء عراق جديد يسعى للمشاركة الفاعلة في الحضارة الانسانية.

r- ت تمكين الطلب مـن تطبيـق المعـارف في الخبـرات والمهارات العلميـة والتنربويـة، النظريـة

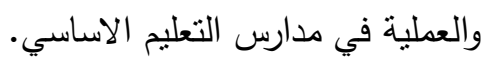

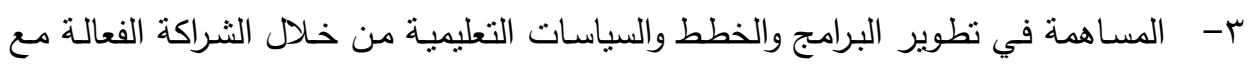

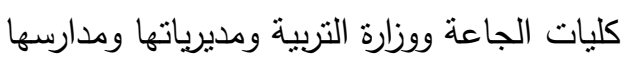

ع- - تطوير وتحسين التخصصـات العلمية، في ضوء النظريات المعاصـرة والبحوث وافضل الممارسات في الميادين التربوية والعلمية.

0 - اعداد معلمين على درجة عالية من الكفاءة والتعليم مستمين بعمق المعرفة في مجال

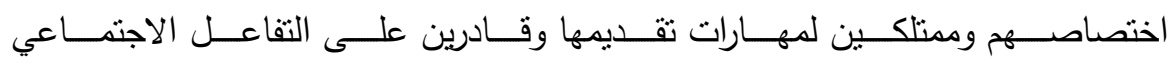

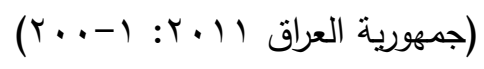


ان الاتجاهات الحديثة في التدريس ركزت على استراتيجيات ماوراء المعرفية والتي تسـاعد

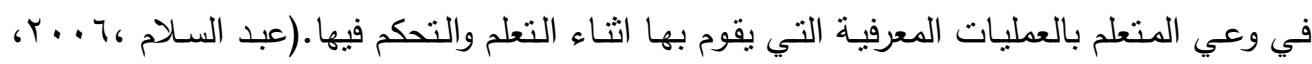
ع • ( )، وتعد استراتيجية k.w.L من الاستراتيجيات مـا وراء المعرفيـة والتي توكد على جعل الطلبـة

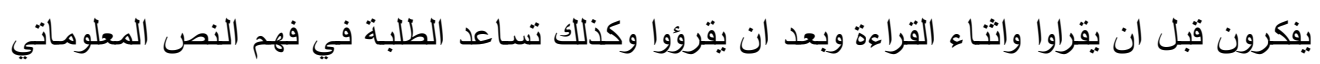

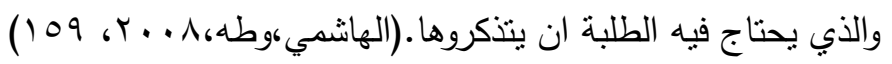

وقد أوصـت الكثير من المؤتمرات والندوات والحلقات الدراسية بأهميـة نشـر الوعي الصـحي لدى المتعلمين ومجتمعهم من خـلال نزويـدهم بالمعلومـات والسلوك الصـحي السـليم، فقد أوصـت الندوة العلمية لمناهج التعليم العام في دول الخليج العربي، 990 بالعمل على نشر الوعي الصحي بين المتعلمين، ووضع إستراتيجية واضحة تؤكد أهمية دور المعلم في رعاية صحة تلامذته وتتمية وعيهم

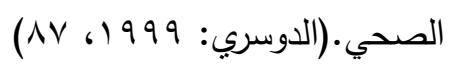

أكدت الحلقات الإقليمية حول التخطيط للبرنامج الصحي في البيئة المحيطة في (مدينة الرياض، آذار

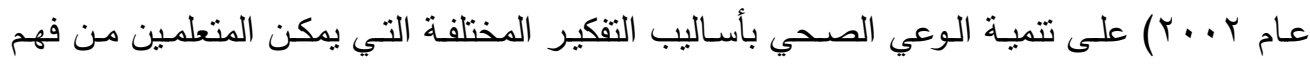

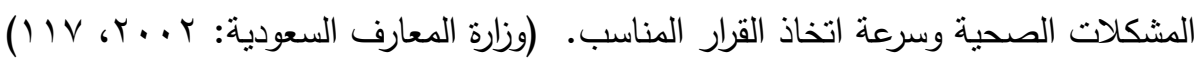

وتتجلى أهميـة هذه الدراسـة بعلاقتها الوثيقة بالتربيـة الصحية وهي بمفهومها الحديث ليست مجرد

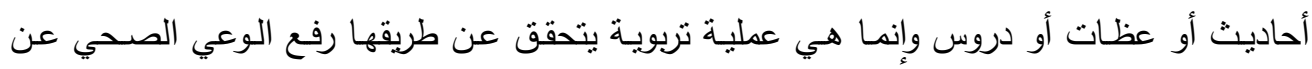
طريق تزويد الفرد بالمعلومات والخبرات بقصد التأثنير في معرفته وسلوكه من حيث صحته وصحة

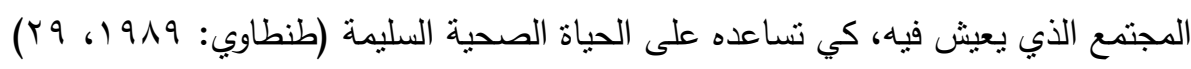

والوعي الصحي يتضـن المفاهيم العقلية والروحية والاجتماعيـة المرتبطة بحياة الإنسان وليس فقط

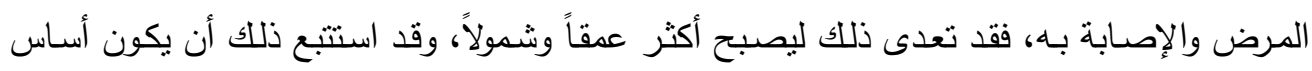
التربية الصـحية متسعاً، وأن يشمل كل العوامل ذات الصلـة بحيـاة الأفراد جسمياً وعاطفياً وانفعالياً

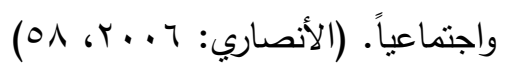

k.w.L وهذا كله دعا الباحثان إلى تجريب طريقة تدريسية حديثة في تدريس العلوم وهي استراتيجية 
العــــــد الثـــامن عشــر

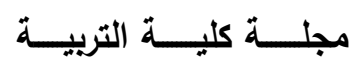

هدف البحث:

يرمي البحث الى تعرف اثر استراتيجية K.W.L في تتمية الوعي الصحي لدى طلبة كلية التربية الاساسية .

فرضبة البحث:

لتحقيق هدف البحث لابد من التحقق من صحة الفرضية الاتية:

((لايوجد فرق ذو دلالة احصائية عند مستوى دلالة (5..0) بين متوسط الفرق بين درجات المقياس (القبلي والبعدي) لطلبة المجموعة التجريبية التي تدرس وفقا لاستراتيجية ومتوسط الفرق بين درجـات المقياس (القبلي والبعدي) لطلبـة المجموعـة الضـابطة التي تدرس بالطريقـة الاعتياديـة في مقياس الوعي الصحي)() حدود البحث: يقتصر البحث الحالي على: 1- طلبة المرحلة الثانية كلية التربية الأساسية الجامعة المستتصرية.

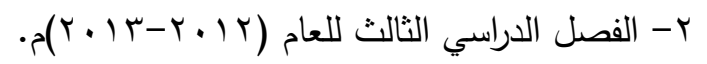
ب- مادة التربية الصحية بمفرداتها المقررة لطلبة السنة الثانية في أقسام كلية التربية الأساسية. : تحديد المصطلحات :

الاستراتيجية : n

عرفها قطامي وقطامي I . . ب :"بأنها جملة من المبادىء والقواعد والطرائق والاساليب المتداخلة التي توجه اجراءات المدرس في سعيه لتتظيم خبرات التعلم الصفي وتحقيق النتاجـات المرصدة"(قطامي

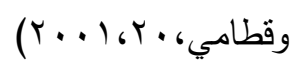


العــــــد الثــامن عثــر

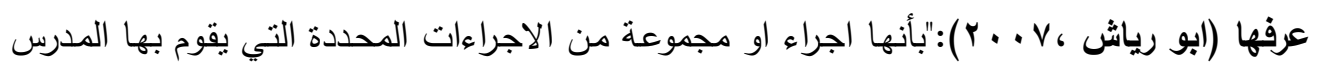
لجعل عملية التعلم اكثر سرعة وسهولة ومتعة ،وموجهة ذاتيا بشكل اكبر ،فضلا عن قابليتها للانتقال

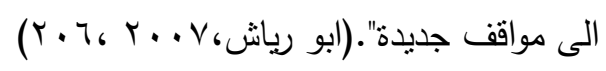

ويعرفها الباحثان "بأنها مجموعة من الاجراءات والخطوات التي يحددها الباحث لتوجه تدريسـه لطلبة المجموعة التجريبية لتحقيق تعلم افضل"

: K.W.L استراتيجية

عرفها (العليان ،0 . . r): هي احدى استراتيجيات ما وراء المعرفة والتي تتكون من ثلاث خطوات يشير اليها كل حرف باللغة الانكليزية على النحو الاتي:

What I know?

$$
\text { ويقصد بها ماذا يعرف المتعلم عن الموضوع؟ }
$$

W

What I Want to learn?

ويقصد بها ماذا يريد المتعلم ان يتعلم عن الموضوع؟

L what I did learn?

ويقصد بها ماذا تعلم المتعلم عن الموضوع؟

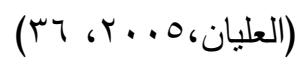

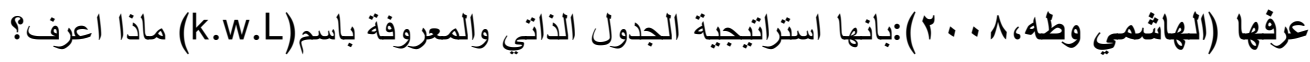

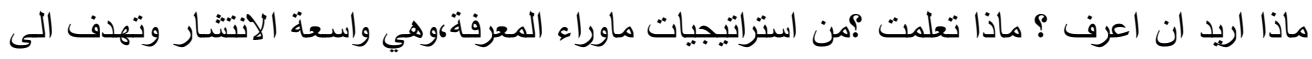

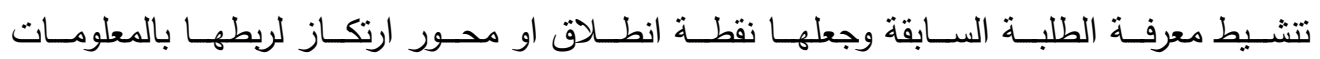


الجديدة،وتتكون من مجموعة خطوات او ممارسات يتبعها المعلم داخل الصف بحيث تساعده على

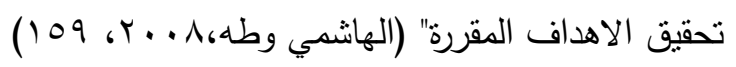

وعرفها الباحثان اجرائياً:بانها استراتيجية تعليمية تصمم على شكل جدول ذاتي لكل طالب ومقسم الى ثلاث اقسام كل قسم يتضمن الاسئلة على التوالي (ماذا اعرف ؟وماذا اريد ان اعرف؟ وماذا تعلمت جاته ؟)بحيث تضمن الاجابـة عن كل سؤال توضيح شـامل لموضـوع الدرس كونـه يجعل الطالب يفكر ويستتتج ويحلل للوصول الى المعلومات.

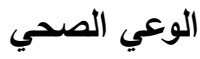

- عرفته (منظمة الصحة العالمية: 919 (1) بأنه: هو تطبيق واسع من الخبرات التعليمية بغية تسهيل تكييف نمط حياة المتعلم مع الممارسات الصحية الجيدة تكيفاً طوعياً من خلال خبرات التعلم المتصفة بالمشـاركة الإيجابيـة مـن أجـل التوصـل إلى تقبـل الثـخص لمهـارات الصـحة الجيـدة وممارسـتها".

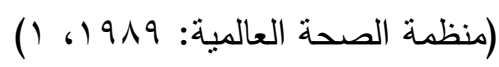
-جاء كلمة الوعي في المعجم الوجيز (مجمع اللغة العربية، 991 ( ) بثلاث صياغات هي:الحفظ والتقدير والفهم، سـامة الإدراك، شـعور الكـائن الحسي بمـا في نفسـه ومـا يحيط بـالآخرين.

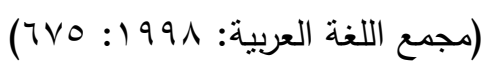

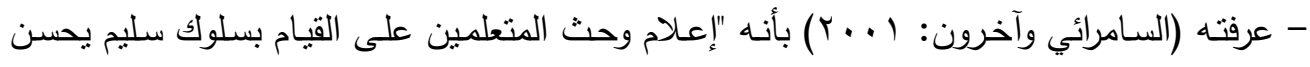

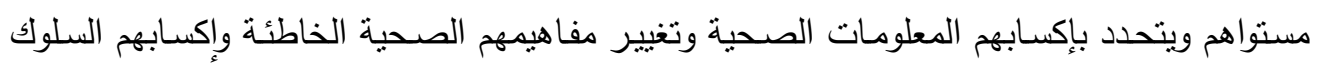
السليم والاتجاهات الصحية الإيجابية".

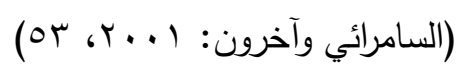

- عرفه (Connie: 2001) بأنه "عملية تحفيز وإقناع المتعلمين لتعلم ممارسة صحية صحيحة أو عملية ترجمـة الحقائق والمفاهيم الصحية المعروفة إلى أنماط سلوكية صحية سليمة تؤدي إلى رفع 


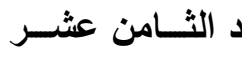

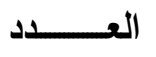

(Connie: 2001,25)

-وكلمة الوعي يقابلها في الإنجليزية aware وقد جاء معناها في قاموس أكسفورد

Having Knowledge or understanding or notice

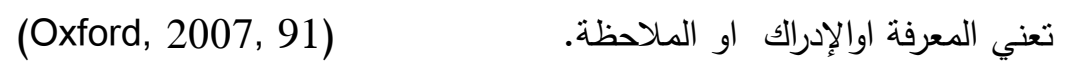

-التعريف الإجرائسي: هو خبرة مكتسبة تؤدي الى ممارسات وعادات صحية مرغوبـة والتي تتمثل بالدرجات التي يحصل عليها طلبة عينة البحث في مقياسي الوعي الصحي القبلي والبعدي. 
K.W.L اولاً:إستراتيجية الجدول الذاتي

استراتيجية قدمتها دونا اوغل (Donna Ogle 1986) بهدف تتثيط عمليات التفكير قبل واثثاء وبعد دراسة الموضوع،وتساهم هذه الاستراتيجية في تتمية المعرفة السابقة لاى الطلبة وتعميق الفهم وفي متابعة عمليات التعلم وحل المشكلات.

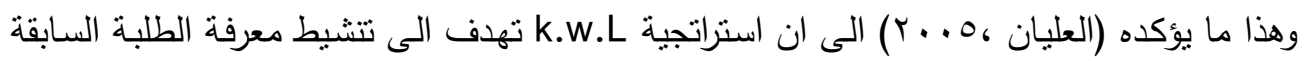

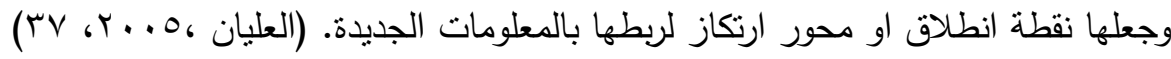
- مميزات استخدام استراتيجية K.W.L في الترريس: - تساعد على تذكر المعلومات السابقة عن الموضوع. -تبين الغرض من المعلومات الواردة في الدرس عن الموضوع. - تساعد الطلبة على منابعة الفهم وتقييم فهم الموضوع. -تقدم فرصة لتوسيع نطاق افكارالموضوع. - تعزيز فكرة التعلم التي تجعل المتعلم محور العطلية التعليمية بدلا من المعلم. - تساهم في جذب اهتمام المتعلمين واثارة فضولهم. - تسهم في تحسين الفهم وتجعل التعلم ذي المعنى. - يمكن تطبيقها في كل المستويات الدراسية.

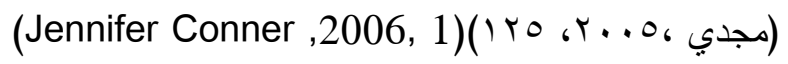

K.W.L خطوات تطبيق استراتيجية- 
r .مناقثة الموضوع لتهيئة اذهان الطلبة وزيادة دافعيتهم وانتباههم.

$$
\text { ؟ ع.رسم الجدول الذي يمثل استراتيجية الدرس على السبورة. }
$$

ه.يملا الطلبة الجزء الاول من الجدول عما يعرفون عن موضوع من خلال المناقشّة ،اذ تعد الخبرة السابقة هي الاساس الذي ينطلق منه الطلبة لبناء معرفة جديدة للتوجه نحو التعلم.

7 ـيوجه اهتمام الطلبة الى الجزء الثاني من الجدول والذي يتضمن مااريد ان اتعلمه؟ بمساعدة المعلمة من خلال طرح اسئلة حول المطلوب معرفته عن الموضوع الجديد ،يضع الطلبة اجوبـة للاسئلة التي طرحت كيتم الصحيح منها ،بذلك تكون المتعلمة هنا منتجة وليست مستهلكة.

V.تدون اجابات الطلبـة في الجزء الثالث من الجدول على الاسئلة البحثيـة وتسجيل مـا تعلمه عن الموضوع وبهذا تتتج الصورة النهائبة للتعلم.

\section{ثانياً: الوعي الصحي:}

الوعي الصحي يعني تبني الفرد لممارسات صحية سليمة ويعمل على أحداث تغييرات صحية في بيئته

لذلك فإن الوعي الصحي يعمل على تغيير وجهات نظر المتعلمين في سلوكهم وممارساتهم الصحية، وإذا ما أراد المعلم أن ينمي الوعي الصحي لدى طلبته فعليه أن يحفزهم على ترجمة الحقائق

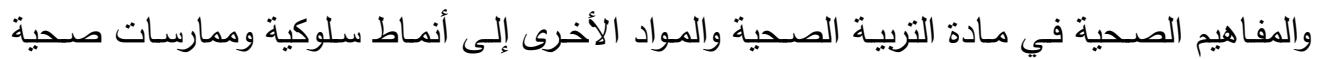
(Connie:2001, 25) سليمة لكي تؤدي إلى رفع المستوى الصحي لديهم 
إن عملية التغيير المرغوبة هذه تمر بمراحل مميزة ومتسلسلة قبل أن يتمكن المتعلم من إتباع السلوك الصحي الجديد ويمنلك وعياً صحياً مميزاً، وبنبغي على المعلم فهم هذه المراحل جيداً، لكي تكون عملية التغيير ناجحة، ويمكن تحديد مراحل التغيير بالآتي:-

ا- المرحلة الأولى/ الوعي: وفيها يتعرف المتعلم على الأفكار الصحية والسلوك الجديد بصورة عامـة من خلال معرفة فائدته ومدى إمكانية تحقيقه وما هي العقبات التي ممكن أن تعترض طريقه.

ץ- المرحلة الثانيةة/ الاهتمام: وفيها يبحث المتعلم فيها عن تفاصيل أكثر عن المعلومات الصحية المقدمة إليه ويكون أكثر استعداداً للقراءة أو الإصغاء عن الموضوع الصحي المقدم له.

ץ- المرحلة الثالثة/ التقييم: وفيها يقدر المتعلم السلبيات والايجابيات للسلوك الصحي، ويحاول أن

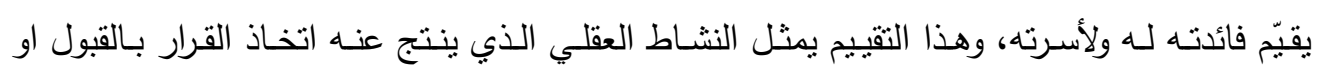
بالرفض.

ع - المرحلة الرابعة/ المحاولة: وفيها يتم تتفيذ القرار بشكل عملي وهنا يحتاج المتعلم إلى معلومات

إضافية ومساعدة حتى يعمل على حل المشكلات التي تعترض طريق تطبيق القرار .

ه- المرحلة الخامسـة/ الاقتتـاع: وفيها يكون المتعلم مقتتعاً بصحة السلوك الجديد ويقرر القيام بـه

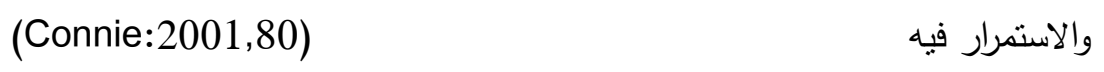

و يمكن تحديد ثلاثة أهداف رئيسة للوعي الصحي:-

ا- توجيه المتعلمين لاكتشاب المعلومات الصحية:- للقضاء على حواجز الجهل والمفاهيم الخاطئة

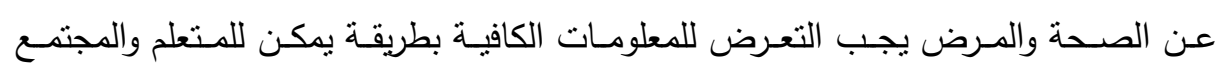
استيعابها بسهولة مما يؤدي ذلك إلى تحمل كل متعلم مسؤوليته عن الرعاية الصحية أكثر من الاعتمـاد على مقدمي الخدمـة الصـحية التقليديين فالمعلومـات التي تم نقلهـا يجب أن تزيــ الوعي عن الاحتياجـات والمشـاكل الصـحية وكذلك تقرب المسـافة بين الاحتياجـات الفعليـة والاحتياجـات المحسوسـة ممـا يسـاعد على مشـاركة المجتمـع في التخطبط للرعايـة الصـحية الأولية.

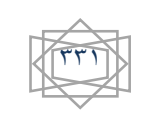


r- حث المتعلمين على تغيير مفاهيمهم الصحية: على الرغم من صحة المعلومات لتغيير المفاهيم

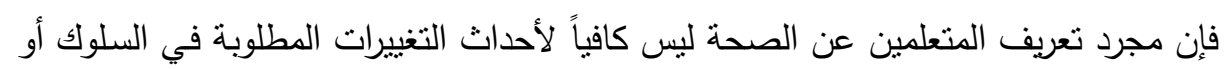

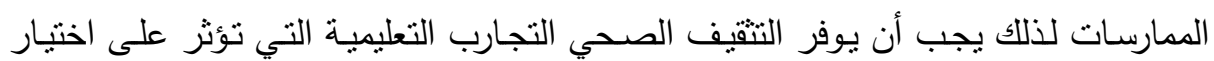

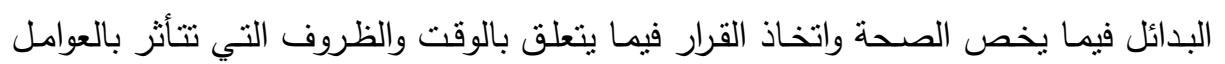
الأخرى.

r- توجيه المتعلمين لإتباع السلوك السليم المرغوب فيه وما سبق ذكره من أنشطة ينسع كل منهما

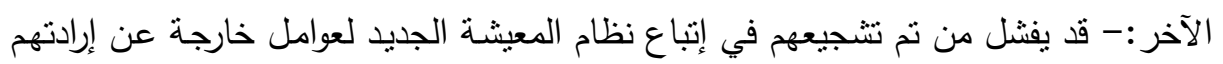

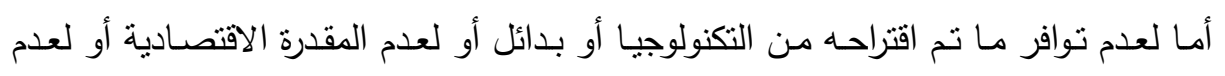
المتابعة المستمرة من المركز الصحي لذلك فإن مسؤولية المركز الصحي ليست فقط تقديم

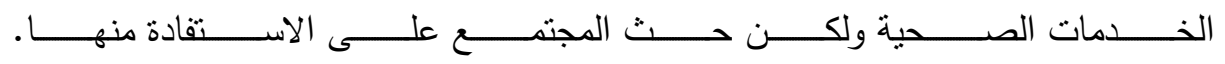

(Net 1:2007) 
الفصل الثالث :الدراسات السابقة:

\section{Sراسات تناولت استراتيجية K.W.L}

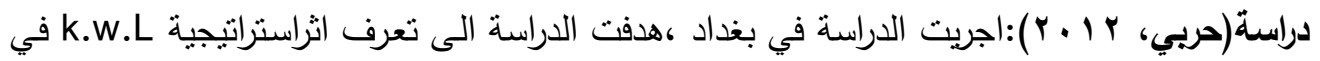
امتلالك طالبات المرحلة المتوسطة للأكاءات المتعددة في مادة الرياضيات.

تكونت عينة الدراسة من(·r)طالبة من طالبات الاول المتوسط بواقع(ro)طالبة في كلا المجموعتين

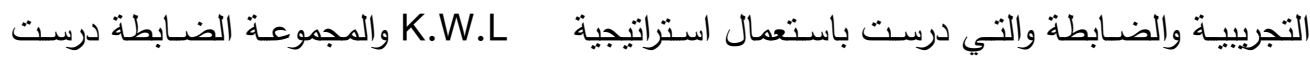

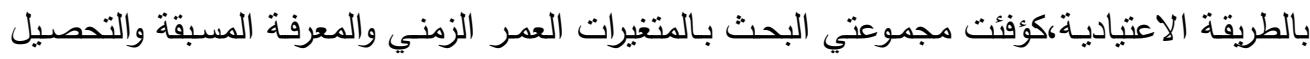

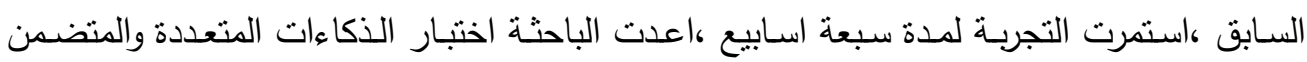
ثلاث انواع من الذكاءات وهي البصري والمنطقي واللفظي وبصورة الاختيار من متعدد اذ تكون

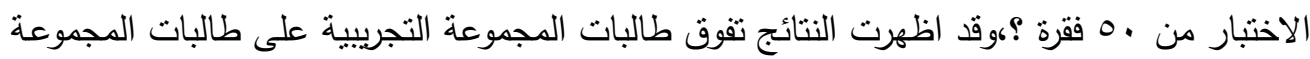

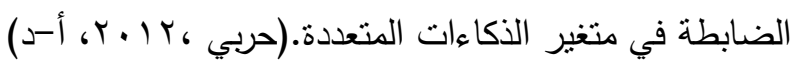

\section{دراسات تناولت الوعي الصحي:}

- دراسة (2002, Tonya): أجريت الدراسة في بريطانيا (ليفربول)، هدفت الدراسة إلى معرفة اثر

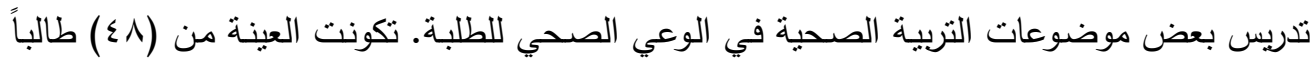

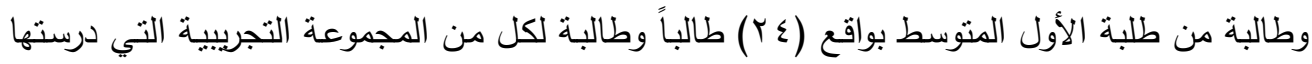

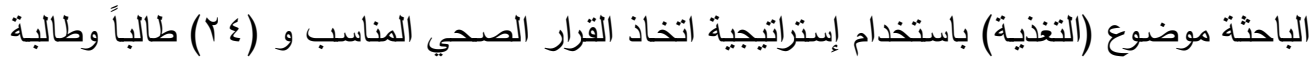
لللمجموعة الضابطة التي درست بالطريقة الاعتيادية.

استغرقت الدراسـة أربعة أسـابيع، أعدت الباحثة اختبار المعلومـات الصحية الذي تكون من

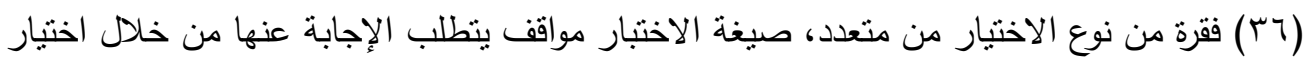

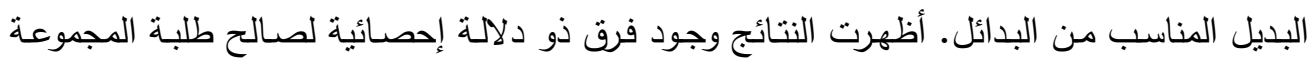
(2002:Tonya) 
العــــــد الثــامن عشــر

\section{مجلــــة كليــــة التربيــــة}

- دراسة (الحساني: ؛ . . †): أجريت هذه الدراسة في العراق (مدينة بغداد)، هدفت هذه الدراسة إلى التعرف على أثر تدريب معلمي العلوم على وفق برنـامج تدريبي مقترح في تتميـة الوعي الصـحي

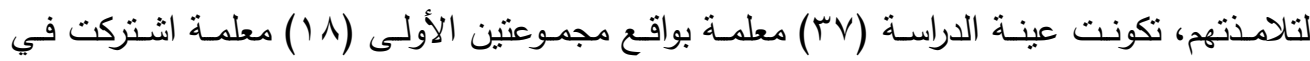
البرنامج التدريبي المقترح في التربية الصحية، الثانية (9 ( ) معلمة لم نشترك في البرنامج التدريبي.

كما كانت عينة التلامذة ( • (s) تلميذ وتلميذة بواقع مجموعتين تجريبية ضابطة، طبق الباحث اختبـار وعـي صـحي يتكـون مـن ( • ع) فقرة أسفرت النتائج عـن وجـود فرق دال إحصـائياً لصـالح المجموعة التجريبية التي اشتركت في البرنامج التدريبي. أبي أن البرنامج المقترح في التربية الصحية لمعلمي العلـوم أثنر ايجابيـاً في تتميـة الوعي الصـحي لتلامـذتهم مسن خـلال زيـادة كفـاءة معلميهم.

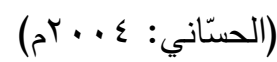


العــــــد الثــامن عثــر

مجلــــة كليــــة التربيــــة

الفصل الرابع إجراءات البحث :يتتاول هذا الفصل عرضاً للإجراءات المتبعة لتحقيق أهداف البحث

وفرضياته وكما يأتي:

أولا: التصميم التجريبي:

التصـميم التجريبي عبـارة عن مخطط وبرنـامج عمل لكيفيـة تتفيذ التجربـة، ونعنـي بالتجربـة

تخطبط الظروف والعوامل المحيطة بالظاهرة التي تدرسها بطريقة معينة ثم ملاحظة ما يحدث؟ (عبد

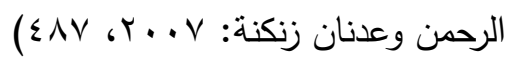

أختار الباحثنان التصميم التجريبي ذا الضبط الجزئي ذات المجموعتين التجريبيـة والضـابطة

ذات الاختبار القبلي -البعدي لنتمية الوعي الصحي والبعدي للتحصيل.

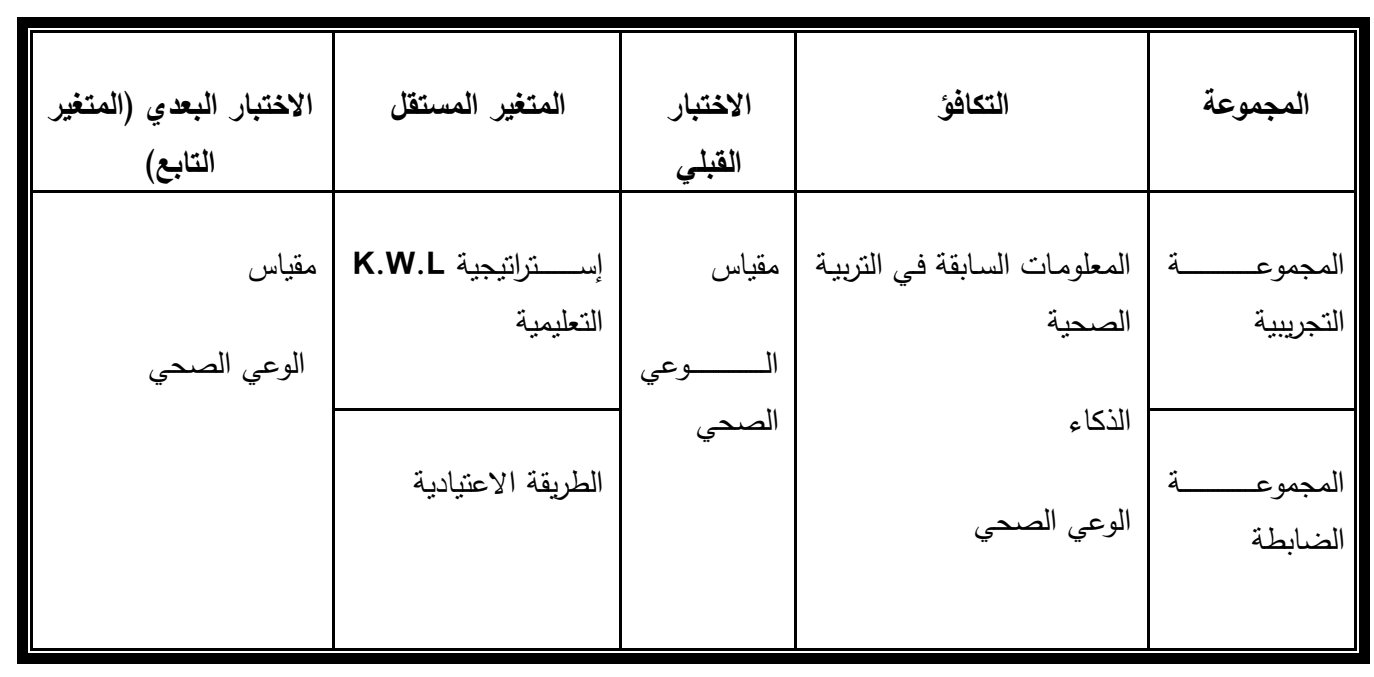

مخطط (1)التصميم التجريبي لمتغيرات البحث 
العـــــد الثـــامن عشــر

\section{- مجتمع البحث وعينته: Research population and Sample}

اختار الباحثان طلبة كلية التربية الأساسية/الجامعة المستصرية مجتمعاً لبحثهما بشكل قصدي

أمـا طريقـة اختيـار الثـعب فقد لجـأ الباحثنان إلىى التعيين العشـوائي وهـي مـن أبسط أنواع العينـات العشوائية (الاحتمالية) حيث يعطي فرصة لكل أفراد المجتمع بالظهور في العينة وهناك أساليب محددة

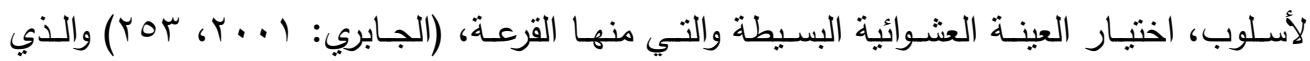
اعتمدها الباحثنان في اختيـار الثـعب من مجموع ثناث تخصصـات فيزيـاء، وأحياء، وكيمياء، تم اختيار شعبتي الكيمياء والأحياء.

بالتعيين العشوائي خصصت طلبة تخصص الأحياء كمجموعة تجريبية وكان عددها (r) طالباوطالبة وتخصص الكيمياء كمجموعة ضـابطة وعددها (TY) أما طلبة تخصص الفيزياء والذي كان عددها (Y (Y) فاعتمدها الباحثان كعينة استطلاعية وبعد استبعاد الطلبة الراسبين أصبح عدد أفراد العينة النهائية (YV) طالب في تخصص علم الأحياء و (Yo) طالب في تخصص علم الكيمياء وكما

$$
\text { موضتح في جدول (r). }
$$

جدول(1) يوضح توزيع عينة البحث بين المجموعتين التجريبية والضابطة

\begin{tabular}{|c|c|c|c|c|}
\hline عدد أفراد العينة النهائي & عدد الرسوب & عد أفراد العينة & الشعبة & المجموعة \\
\hline$r V$ & 0 & r & تخصص علم الأحياء & التجريبية \\
\hline ro & 1 & rT & تخصص علم الكيمياء & الضابطة \\
\hline or & 7 & 01 & ش & المجموع \\
\hline
\end{tabular}


ويقصد به إجراء التكافؤ في خصائص المجموعتين التجريبية والضـابطة لمعرفة أثر المتغير المستقل

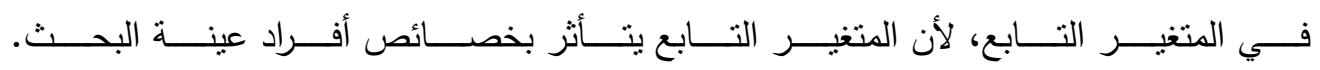

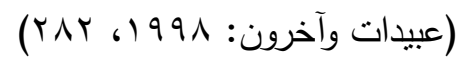

لذا تم إجراء التكافؤ بين مجموعتي عينة البحث في عدد من المتغيرات التي يعتقد الباحثنان أنها تؤثز في نتائج التجربة ومنها:

\section{1- المعلومات السابقة في التربية الصحية:}

من أجل التحقق من تكافؤ مجموعتي البحث في مقدار ما يملكونه من المعلومات السابقة في التربية الصحية تم إعداد اختبار مكون من (·r) فقرة اختبار من متعدد وتم عرضـها على الخبراء والمختصين في مجال التربية وطرائق تدريس العلوم، علوم الحياة للتحقق من صدق فقرات الاختبار ، ثم طبـق الاختبـار على المجمـوعتين (الضـابطة و التجريبيـة) ، إذ بـــغ المتوسـط الحسـابي لطلبـة

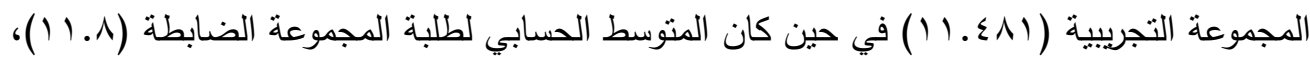
وعند إجـراء المقارنـات بين متوسطي المجموعتين التجريبيـة والضـابطة وباستعمال الاختبـار التائي لعينتين مستقلتين وبدرجـة حريـة (•0) لـم يظهر هنـاك فرق ذو دلالـة إحصـائية عند مستوى دلالـة (0 •، • ) ويوضـح الجدول (r) ذللك مما يدل على تكافؤ المجموعنين في هذا المتغير. 
العــــــد الثـــامن عشـــر

جدول (Y)(المتوسط الحسابي والتباين والقيمة التائية المحسوية والجدولية لمتغير المعلومات السابقة للاختبار لمجموعتي البحث

\begin{tabular}{|c|c|c|c|c|c|c|c|}
\hline \multirow{2}{*}{ 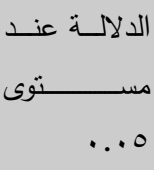 } & \multicolumn{2}{|c|}{ القيمة التائية } & \multirow{2}{*}{ درجـــة } & \multirow[t]{2}{*}{ التباين } & \multirow{2}{*}{ المتوســـ الحسابي } & \multirow{2}{*}{ عــــــدد } & \multirow[t]{2}{*}{ المجموعة } \\
\hline & الجدولية & المحسوبة & & & & & \\
\hline \multirow[t]{2}{*}{ غير دالة } & \multirow[t]{2}{*}{ r...11 } & \multirow[t]{2}{*}{.$r 11$} & \multirow[t]{2}{*}{0.} & rr... & $11 . \Sigma \Lambda 1$ & rV & التجريبية \\
\hline & & & & $r v .9 \leq 0$ & 11.1 & ro & الضابطة \\
\hline
\end{tabular}

r- الذكاء Intelligence: من اجل التحقق من تكافؤ مجموعتي البحث في متغير الذكاء طبق الباحث اختبار رافن (Raven) المقنن والمعرف في جامعة الموصل لاستعماله في إجراء التكافؤ بين مجموعتي البحث التجريبية والضـابطة، لأنه يتصف بدرجة من الصدق والثبات ملائم للبيئة العراقية، ولأنه اختبار غير لفظي يمكن تطبيقه بسهولة على مجموعات من الأفراد في آن واحد.

ويتألف الاختبار من خمس مجموعات من اللوحات (أ، ب، ج، د، هـ) وتضم كل مجموعة اثتني عشرة لوحة، وبذلك يتألف الاختبار من ( • ؟) لوحة لكل منها درجة واحدة للإجابة الصحيحة، وبذلك

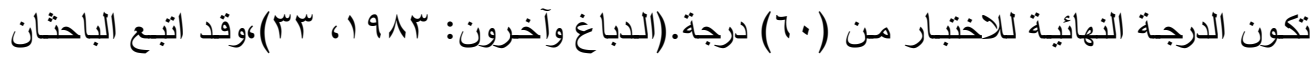
تعليمات تطبيق الاختبار بدقة والتي تم توضيحها لأفراد عينة البحث، وثم تطبيقها على أفراد عينة البحث قبل تتفيذ التجربة ولكلا المجموعتين. 
العــــــد الثــامن عثــر

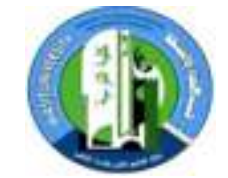

مجلــــة كليــــة التربيــــة

جدول (ץ)المتوسط الحسابي والتباين والقيمة التائية المحسوية والجدولية لمتغير الذكاء لمجموعتي

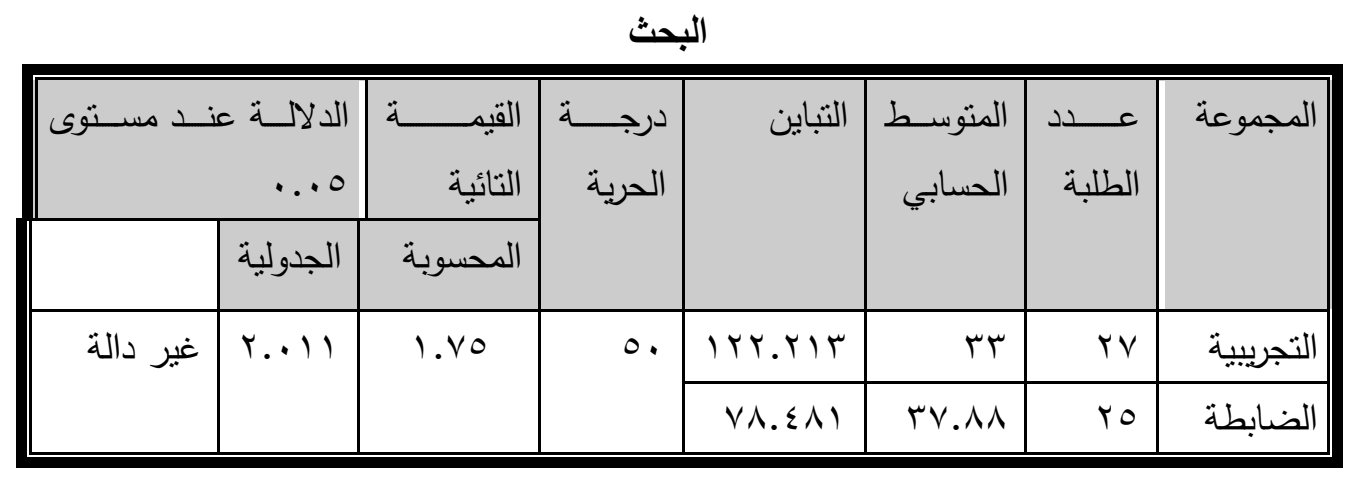

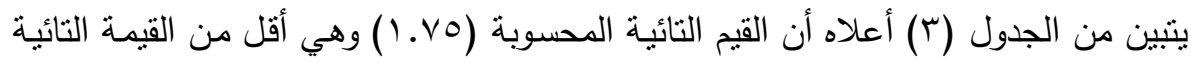

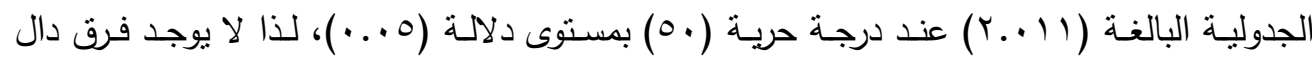

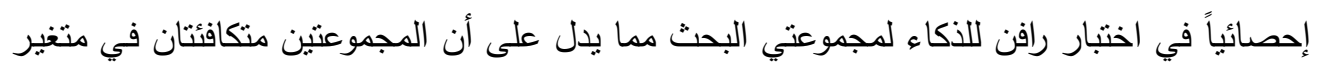
الأكاء.

ץ-المقياس القبلي للوعي الصحي: أعد الباحثان فقرات لقياس الوعي الصحي وتم عرضها على الصى الخبراء والمختصين في مجال التربية الصحية وطرائق تدريس العلوم وبالاستتاد إلى فقرات المقياس

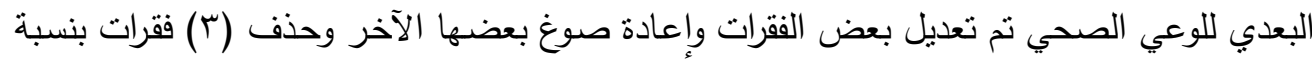

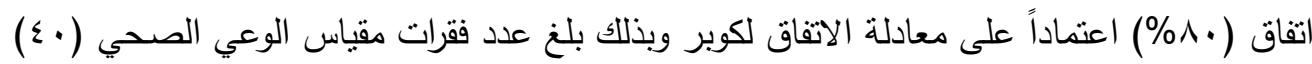
فقرة.

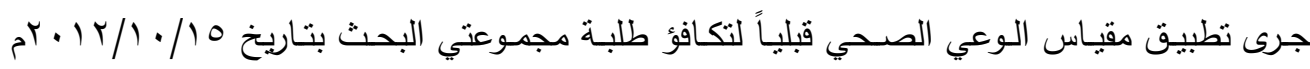
الموافق يوم الخميس على طلبة المجموعتين (التجريبية والضابطة).

إذ بلغ المنوسط الحسابي لطلبة المجموعة التجريبية (Y.r. (Y) في حين كان المتوسط الحسابي لطلبة

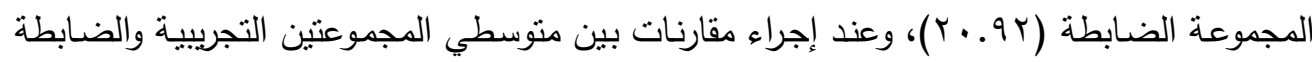

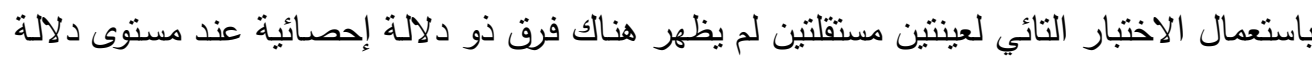

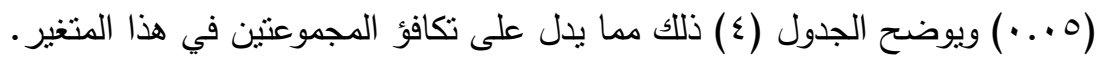


جدول ( ) المتوسط الحسابي والتباين والقيمة التائية المحسوية والجدولية لمتغير الوعي الصحي للمقياس القبلي لمجموعتي البحث

\begin{tabular}{|c|c|c|c|c|c|c|c|}
\hline \multirow{2}{*}{ 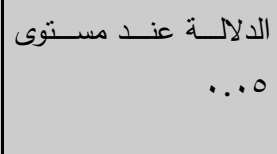 } & \multicolumn{2}{|c|}{ القيمة التائية } & \multirow{2}{*}{ درجـــــة } & \multirow[t]{2}{*}{ التباين } & \multirow{2}{*}{ الحتوســـــــــ } & \multirow{2}{*}{ عـــــد } & \multirow[t]{2}{*}{ المجموعة } \\
\hline & الجدولية & المحســـو & & & & & \\
\hline \multirow[t]{2}{*}{ غير دالة } & \multirow[t]{2}{*}{$r . .1$} & \multirow[t]{2}{*}{..$\leqslant 1$} & \multirow[t]{2}{*}{0.} & 17.19 & YI. rV & $r V$ & التجريبية \\
\hline & & & & $1 \leq . r q$ & $r . .9 r$ & ro & الضابطة \\
\hline
\end{tabular}

لرابعاً: إجراءات الضبط الاخرى: ويقصد به التأكد من السلامة الخارجية والداخلية للبحث ومدى تمثيل أفراد التجربة لمجتمع البحث الذين ينتمون إليه وعلى مدى إمكانية تعميم نتائج التجربة على مجنمع إنع

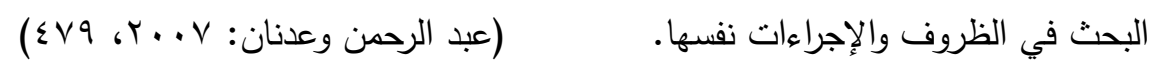

وعليه ولضمان توافر السلامة الخارجية والداخلية للتصميم التجريبي قام الباحثان بالإجراءات التالية:

1- درس احـ البـاحثين مجمـوعتي البحث (التجريبيـة والضـابطة) طـوال مـدة التجربـة بنفسـه تجنبـاً للاختلاف في معاملة الطلبة والخبرة التدريسية لكلا المجموعتين.

ץ- كانت المادة الدراسية موحدة لمجموعتي البحث حيث وزعت المادة العلمية على مجموعتي البحث التجريبية والضابطة.

ب- المدة الزمنية للتجربة كانت منساوية لمجموعتي البحث وهي فصل دراسي (الفصل الثالث) حيث الكلية تعدل بنظام الفصول وتعطى مـادة التربية الصحية في الفصل الثالث للمرحلة الثانيـة

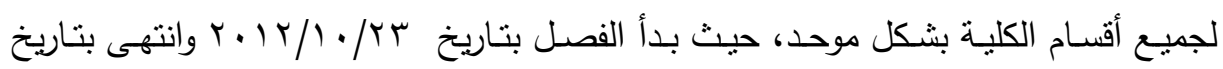

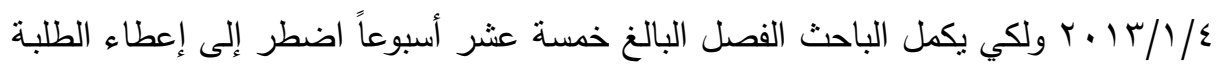
محاضرات تعويضية. 
العـــــدد الثــامن عشـــر

\section{(4) \\ ع - لم يسمح للطلبة بالحضور في غير مجموعتهم. \\ 0- تم إجراء الاختبار في نفس اليوم لكلا المجموعتين.}

צ- كانت القاعات الدراسية منتـابهة في الخصائص الفيزياوبة من حيث أنها تقع في الطابق الثاني وطريقة تأثنتها ومن حيث الإنارة والتهوية.

خامساً:إعداد مستلزمات البحث:

لتحقيق أهداف البحث تطلب إعداد مسنلزماته التي تكونت من:

ا - تحديد المـادة العلميـة: إن محتوى المـادة العلميـة التعليميـة هي المعلومـات والمهارات والأنشطة

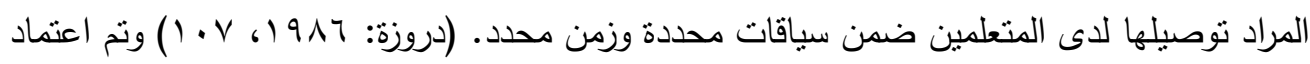
مادة التربية الصحية عن محاضرات للأستاذ الدكتور أحمد عبد الزهرة العكيلي.

ץ- صياغة الأهداف السلوكية: تعد معرفة الأهداف السلوكية وتحديدها من الأمور الهامة جداً في العملية التعليمية، وبقدر ما تكون الأهداف السلوكية واضحة تكون العملية التعليمية ونتائجها أكثر أثراً

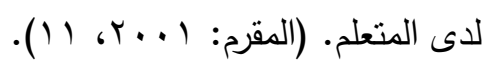

لذا قام الباحثان بصوغ الأهداف السلوكية على نحو واضح واصفاً سلوكاً أو نشاطاً محدداً يقوم بـه المتعلمون، حيث تم توزيعها بين المستويات الستة لتصنيف بلوم (Bloom) المعرفي.

وقد بلـغ عددها (9 · r) غرضـاً سلوكياً ،وقد عرضـت الأهداف السلوكية مـع المحتوى على مجموعة من الخبراء والمختصين في طرائق التدريس لإعطاء آرائهم وملاحظاتهم، وتم تعديل صياغة

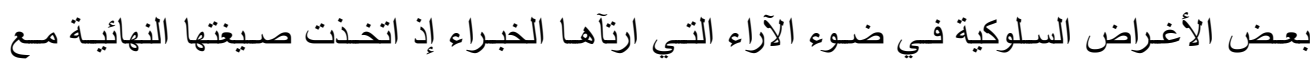
المحافظة على عددها.

r_اعداد الخطط التدريسية: عملية اقتراح سلسة من الإجراءات والخطوات لغرض تحقيق الأهداف التربوية المنشودة للعملية التعليمية من خلال التخطيط الاسبوعي الدقيق المنظم حيث يحسب التدريس 
حساب كل خطوة حرصاً منهه على ضمان النجاح الأكبر في بلوغ الهدف. (مرعي ومحمد: V . . Y،

في ضوء ذلك أعد الباحثنان خططاً دراسية اسبوعية للموضوعات الدراسية لكلتا المجموعتين التجريبية والضـابطة وكان عددها 10 خطة لكل مجموعة، وتم عرض نمـاذج منها على عدد من الخبراء والمختصين في التربية وطرائق تدريس العلوم لإعطاء آرائهم وإجراء التعديلات لبعض عناصر الخطة لضمان ملاءمتها لتدريس مادة التربية الصحية.

\section{سادساً: بناء أدوات البحث:}

حتى يتم تحقيق أهداف البحث تطلب إعداد أدواته المتمثلة في بناء الاختبارات الآتية: - مقياس الوعي الصحي:

تم اعتماد المقياس أداة في البحث الحالي، وهي أداة قياس يتطلب إعدادها طرقاً منهجية تتفق والهدف من المقياس وطبيعـة الموضـوع المراد قياسـه وكذللك طبيعة الفئة المستهدفة. (صباريني:

وبناء على ذلك اتبع الباحثان الخطوات الآتية في بناء مقياس الوعي الصحي:-

* تحديد أهداف المقيـاس: يهدف المقياس إلى قياس الوعي الصحي لطلبة المرحلة الثانية في كلية التربية الأساسية من خلال الكثف عن معلوماتهم واتجاهاتهم الصحية.

* صياغة فقرات المقيـاس:- صمم الباحثنان مقياساً بضم مواقف صحية تطلب من الطلبة تحديد وعيهم بإبداء الموافقة او عدم الموافقة اذ تكون من عدد من الفقرات التي تقيس الوعي الصحي، وهذا النوع من المقاييس يمتاز بالمرونة حيث بستخدم في قياس اهداف تعليمية وجدانية كالوعي او الاتجاه

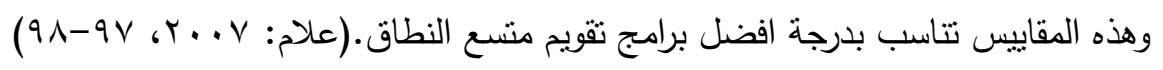

كذللك هذا النوع مـن المقابيس يقلل فرصـة الطالب بالحصـول على الإجابـة بـالتخمين، كمـا يمتاز

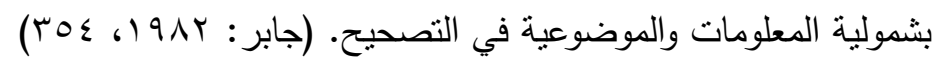


أ. تعليمات للإجابة: وضعت تعلبمات للاجابة عن المقياس تم من خلالها نوجيه الطلبة نحو قراءة كل فقرة بدقة واختيار احد البديلين الموضوعين لكل فقرة ، والإجابة عن جميع الفقرات دون ترك أية فقرة اذ ستعامل الفقرة التي لها اكثر من اختيار او التي تتركك معاملة الفقرات الخاطئة.

ب. تعليمات التصـيح: وضـعت تقدير مناسب لكل فقرة تتراوح بين (• - (1) كما وضـع الباحثنان انموذجا للتصحيح يكون معيار لتصحيح المقياس.

* صــق مقبـاس الـوعي الصـحي: لا يمكن تطبيق المقيـاس دون التحقق من صدقه، والمقصـود

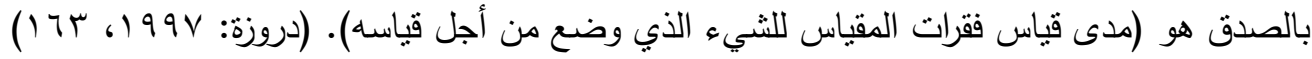
وللتحقيق من مقياس الوعي الصحي ومدى ملائمته لهادة التربية الصحية عرضت فقرات المقياس وتعليماته على عدد من الخبراء والمختصين في مجال التربية الصحية وطرائق تدريس العلوم. كما

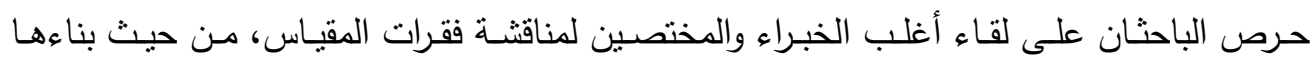

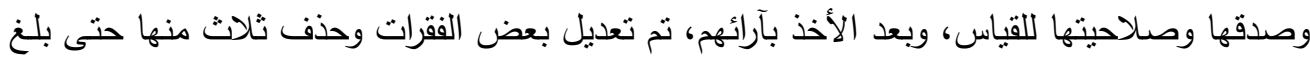
عدد فقرات اختبار الوعي الصحي (•؛) فقرة بصيغتها النهائية، إذ اعتمد الباحثنان منوسط نسبة الاتفاق بين الخبراء والمختصين على فقرات المقياس •^ه\% وفق الاتفاق لمعادلة كوبر حيث مبلغ

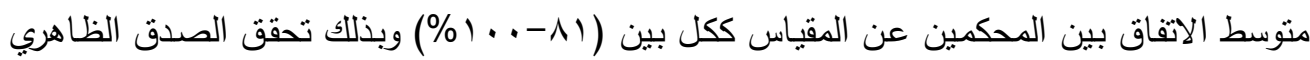

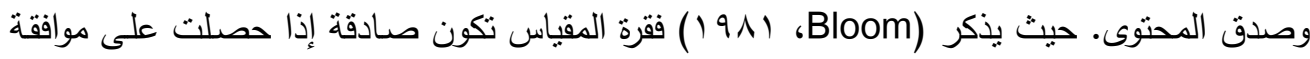
(Bloom:1981, 73) من الخبراء والمختصين. (1\%0)

\section{* تطبيق مقياس الوعي الصحي على العينة الاستطلاعية الأولى:}

طبق مقياس الوعي الصحي على عينة استطلاعية وهي شعبة الفيزياء في قسم العلوم مكونة من

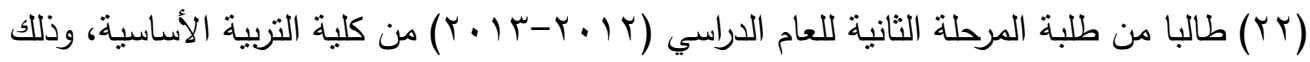

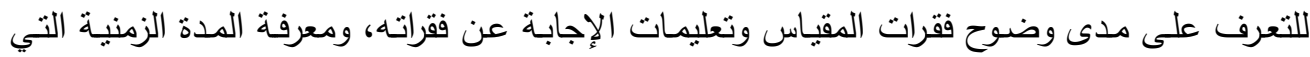




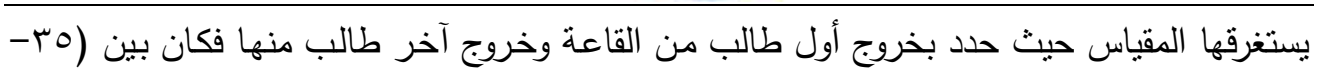
هء ) دقيقة على التوالي، حيث بلغ زمن الإجابة عن فقرات مقياس الوعي الصحي بـ ( • ـ) دقيقة.

\section{تطييق الوعي الصحي على العينة الاستطلاعية الثانبة:}

طبق المقياس على عينة مكونة من (·V) طالب في قسم الرياضيات المرحلة الثانية، وذلك لغرض

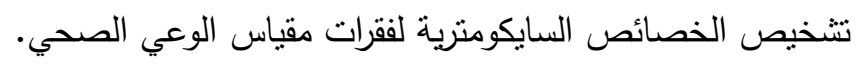

* ثبات مقياس الوعي الصحي: من الخصائص المهمة التي يجب أن تتوفر في المقياس هو الثبات

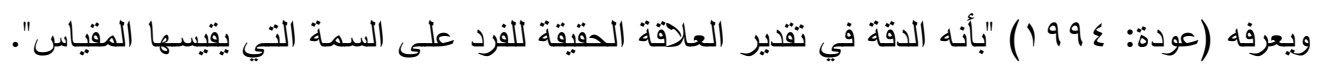

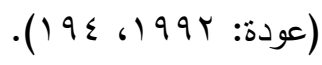

استخدم الباحثان طريقة التجانس الداخلي وتطبيق معادلة كودر ريتشاردسون - ب فبلغ (• 9\%) وهو معامل ثبات جيد بالنسبة لهذا النوع من المقاييس.

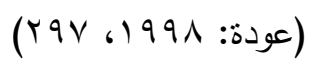

\section{* مقياس الوعي الصحي بصيغته النهائية:}

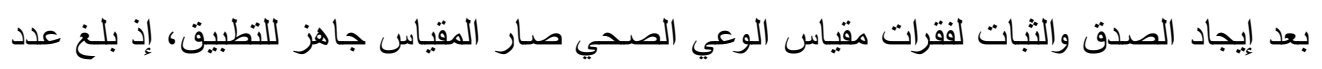

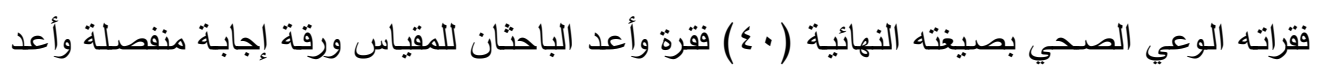

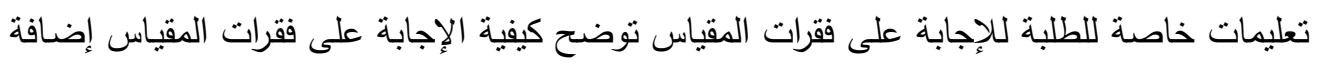
إلى الزمن المحدد للإجابة على فقراته.

* تطيـق مقيـاس الـوعي الصحي: من منطلبات البحث تطبيق مقياس الوعي الصحي في نهايـة

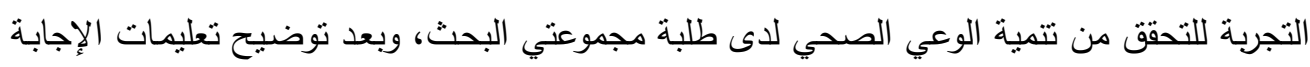

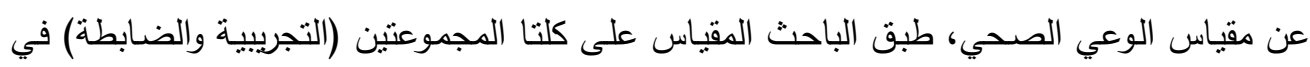

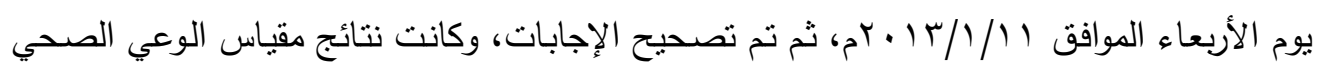
للمجموعة التجريبية والضابطة . 
الفصل الرابع: يتضمن هذا الفصل عرضاً لنتائج البحث وتقسيرها وذكر لأهم الاستتناجات والتوصيات والمقترحات.

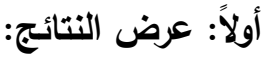 \\ ـ الوعي الصحي:}

لغرض التحقق من فرضية البحث والتي تنص على أنه((لايوجد فرق ذو دلالة احصائية عند مستوى دلالة (5..0) بين متوسط الفرق بين درجات المقياس (القبلي والبعدي) لطلبة المجموعة التجريبية التي تدرس وفقا لاستراتيجية K.W.L ومتوسط الفرق بين درجـات المقياس (القبلي والبعدي) لطلبـة المجموعة الضابطة التي تدرس بالطريقة الاعتيادية في مقياس الوعي الصحي)).

تـم المقارنـة بـين المجمـوعتين التجريبيـة والضـابطة بـالفروق بين المقياسـين القبلي والبعـدي لمقياس الوعي الصحي، وتم ذلك بطرح (درجة المقياس البعدي--درجة المقياس القبلي) لكل طالب في المجمـوعتين، ثم تم حسـاب المتوسـ والتبـاين لفروق درجـات كل مجموعـة على حدة، وباسـتخدام الاختبار التائي لعينتين مستقلتين غير منسـاويتي العدد تم إيجاد القيمـة التائيـة المحسوبة. كمـا في

جدول (0) 
العــــــد الثــامن عثــر

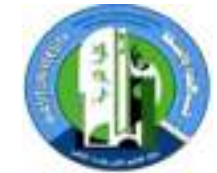

مجلــــة كليــــة التربيــــة

جدول (•)المتوسط الحسابي وتباين الفروق والقيمة التائية المحسوية للقروق لارجات المجموعتين التجريبية والضابطة لمقياس الوعي الصحي القبلي والبعدي

\begin{tabular}{|c|c|c|c|c|c|c|c|}
\hline \multirow{2}{*}{ 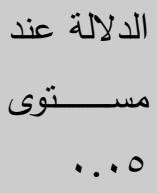 } & \multicolumn{2}{|c|}{ القبمة التائية } & \multirow{2}{*}{ درجــــة } & \multirow{2}{*}{ تبـــــاين } & \multirow{2}{*}{ متوسـط الفروق } & \multirow{2}{*}{ أفــــــــد اد } & \multirow[t]{2}{*}{ المجموعة } \\
\hline & الجدولية & المحسوبة & & & & & \\
\hline \multirow[t]{2}{*}{ دالة } & \multirow[t]{2}{*}{ Y.. II } & \multirow[t]{2}{*}{7.0} & \multirow[t]{2}{*}{0 . } & $0 . V$ & $7 . V$ & rV & التجريبية \\
\hline & & & & $9 . \wedge \varepsilon$ & Y.. $\varepsilon$ & ro & الضابطة \\
\hline
\end{tabular}

يتبين من الجدول أعـلاه أن منوسط الفروق لدرجات طلبـة المجموعـة التجريبية في المقياس

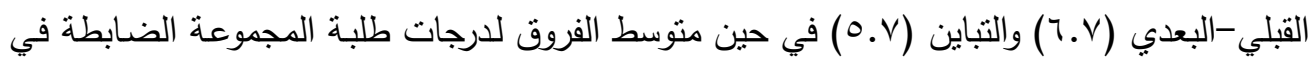

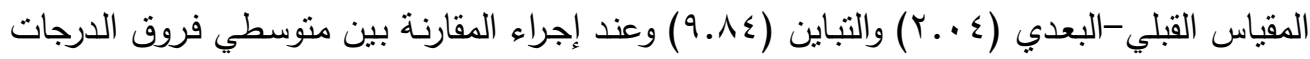
لطلبة المجموعة التجريبية والضابطة وجد أن القيمة التائية المحسوبة (0 . ـ1) أكبر من القيمة التائية

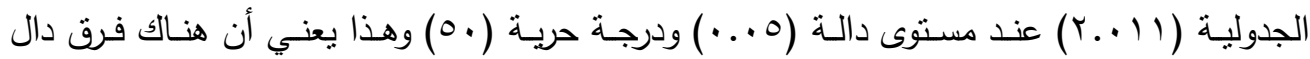
إحصـائياً لصـالح المجموعـة التجربييـة ذات المقيـاس القبلي -البعدي التي درسـت على اسـتراتيجية مما يشير إلى وجود اثر هذا الانموذج في زيادة الوعي الصحي لدى الطلبة وبذلك ترفض الفرضية الصفرية الثانية. ثانياً: مناقشة النتائجج: ا ـ الوعي الصحي:يتضح من النتائج التي توصل إليها البحث ما يأتي:* تفوق المجموعة التجريبية التي درست على وفق استراتيجية K.W.L للتربية الصحية على طلبة المجموعـة الضـابطة التي درسـت على وفق الطريقـة التقليديـة في مقيـاس الوعي الصـحي. ويعـزو الباحثان ذلك إلى عدة أسباب منها:

- عن طريق التدريس وفق استراتيجية K.W.L تضمن تزويد الطلبـة بقدر مناسب من المعلومـات الصحية التي ترتبط بشكل مباشر بمشكلاتهم الصحية وتقديم الأمثلة ومناقشـة مقترحات الطلبة كل ذلك أسـهم في إدراك تأثنيرات هذه المشكلات على الصـحة العامـة للإنسـان وبـللك تكونـت لديهر 
العــــــد الثـــامن عشـــر

مجلــــة كليــــة التربيــــة

اتجاهات ايجابية نحو قضايا الصحة والسلامة للإنسان كما أمدته الأكاديمية القومية للعلوم ( NRC, 1996). كذلك اثراء الخبرة والفهم للظواهر المحيطة والاشتراك في المناقشات حول القضايا العلمية يساعد في استعمال العمليات العقلية في مواقف حياتية أخرى. (NRC:1996,18)

أيضاً أظهر الانموذج إثارة باهتمام الطلبة نتيجة زيادة ثقتهم بأنفسهم وكذلك أوجد روح التتافس بينهم مما أدى ذلك إلى تتميـة الوعي الصحي لديهه. حيث أوضح (بدير ، ^ . . ب) إن استعمال أسـاليب متعددة ومنها المناقشـة التي تتصف بإثارة اهتمام الطلبة مما يجعل دور الطلبة ايجابيا في الدروس ويزيد من ثقتهم بأنفسهم وينمي روح التتافس بين الطلبة وبذلك تساعد في فهم المواضيع والاقتتاع بها

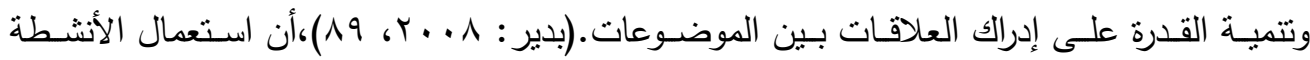
المختلفة يساعد على طرح الأفكار وتفاعل الخبرات بين الطلبة أنفسهم والمدرس وإدراك العلاقة بين

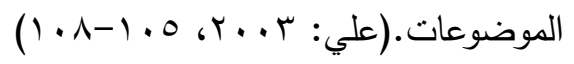
ثالثاً: الاستتتاجات:بناءً على نتائج هذا البحث تم التوصل إلى الاستتناجات الآتية:-

ا - ساهمت استراتيجية K.W.L في تتمية الوعي الصحي لدى طلبة كلية التربية الاساسية. رابعاً: التوصيات: ا - اعتماد استراتيجية K.W.L من قبل مدرس مادة التربية الصحية لأنها تزيد من مقدرة الطلبة على تتمية الوعي الصحي لديهم. ץ- إدخال مفاهيم صحية جديدة في مادة التربية الصحية تواكب مستحدثات العصر لزيادة المعلومات الصحية الحديثة للطلبة ليساعدهم في تتمية الوعي الصحي لديهم. خامساً: المقترحات:يرى الباحثنان إجراء دراسات لاحقة منها:1- إجراء دراسة ممانلة على مراحل أخرى ولمتغيرات أخرى. 


$$
\begin{aligned}
& \text { 1.أبو رياش، حسين محمد وآخرون، (V . . rم) التعلم المعرفي، طا، دار المسيرة، عمان. } \\
& \text { r.بدير، كريمان محد، (^ . . rم): التعلم النشط، طا ، دار المسيرة للنشر والتوزيع، عمان. }
\end{aligned}
$$

r.جابر ، وليد أحمد، (r + .rم): طرق التدريس العامة، تخطيطها وتطبيقاتها التربوية، طا، دار الفكر ، عمان .

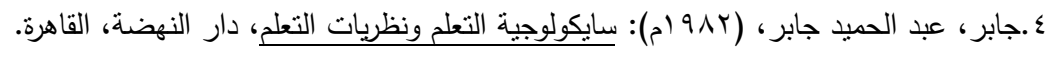

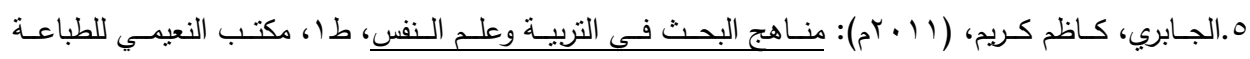
والاستتساخ، بغداد.

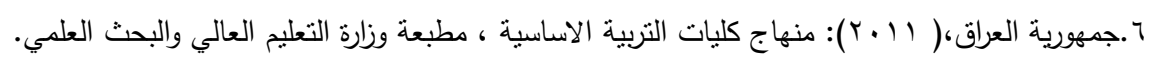

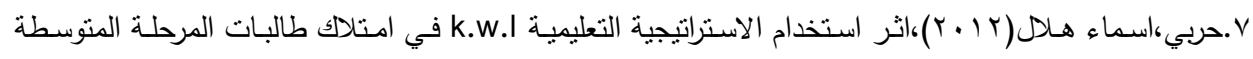
لللكاءات المتعددة في مادة الرياضيات.

^.الحساني، إبراهيم كاظم، (ع rم): "بناء برنامج تدريبي في التربية الصحية لمعلمي العلوم وأثره في نتمية الوعي

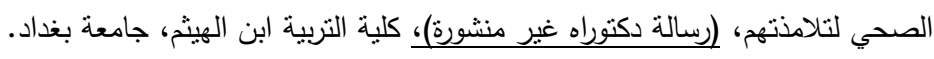

9.الـدباغ، فخـري وآخرون(به (1): اختبـار المصـفوفات المتتابعـة القياسـي المعرفي، مطبعـة جامعـة الموصـل،

• ا .دروزة، افنان، و99 ام نظر : الأسئلة التعليمية والتقييم المدرسي، طب، جامعة النجاح الوطنية، نابلس. 1ا .الدوسري، نجية محمد إبراهيم، (999 (9)): "دراسة حول إذخال الأنشطة الصفية واللاصفية في مجالات التربية

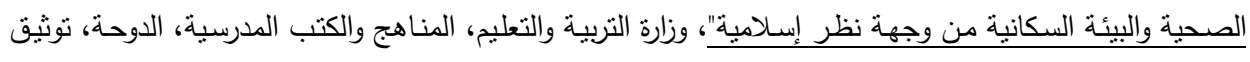
. 90 r ن نيسان.

r السامرائي، أحلام كاظم وآخرون، (1 . ب): الدليل التدريبي للعاملين الصحيين في الرعاية الصحية الولية، وزارة الصحة، بغداد. با .صباريني، محمد سعيد، (1990) ): استخدام الاختبارات التحصيلية في التعليم، مجلة رسالة المعلم، مسقط، العدد 
العــــــد الثـــامن عشــر

\section{مجلــــة كليــــة التربيــــة}

ع ا .طنطاوي، محمود، (9V0 ()): التربية وأثرها في رفع الوعى الصحي، طا ، دار البحوث العلمية، الكويت.

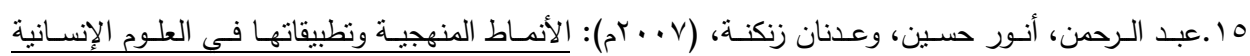

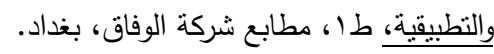

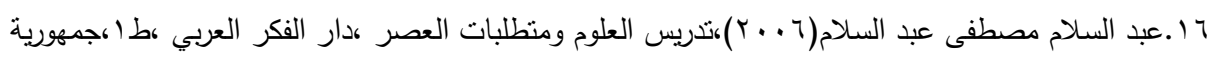
مصر العربية.

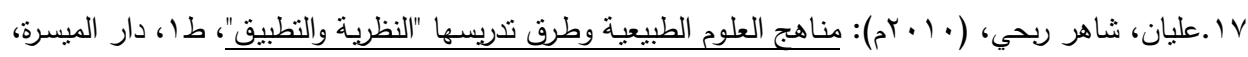
عمان.

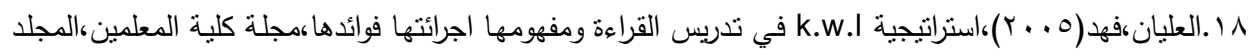
الخامس ،العدد الاول

9 ا.عبيدات، ذوقان وآخرون، (991 (م)): البحث العلمى مفهومه وأدواته وأساليبه، ط7، دار الفكر للنشر والتوزيع، عمان.

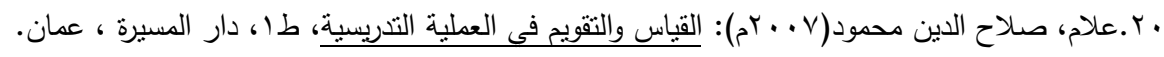
اY. عودة، أحمد سليمان، (999 (م)): القياس والتقويم في العملية التدريسية، طس، دار الأمل ، اربد. r r. علي، محمود السيد، (r . . rم): التربية العلمية وتدريس العلوم، طا، تقويم إبراهيم بسيوني عميرة، دار المسيرة ، عمان.

rr.r.مجدي،عزيز (919 (1)،مناهج البحث العلمي في العلوم التربوبة والنفسية،مكنبة الانجلو،القاهرة. ع ب.مجمع اللغة العربية، (991 ()): المعجم الوجيز، الهيئة العامة لثؤون المطابع الأميرية، القاهرة، مصر. هץ .مرعي، توفيق، والحيلة، محمد(Y . . r): طرائق التدريس العامة، عمان دار المسيرة للنشر والتوزيع والطباعة. צr. المقرم، سعد خليفة، ( ( . r): طرق تدريس العلوم والمبادئ والاهداف، طا، دار الثروق، عمان.

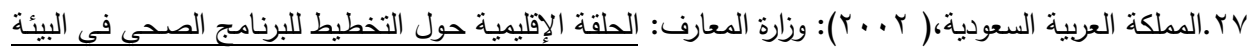
المحيطة، الرياض، ايلول. 


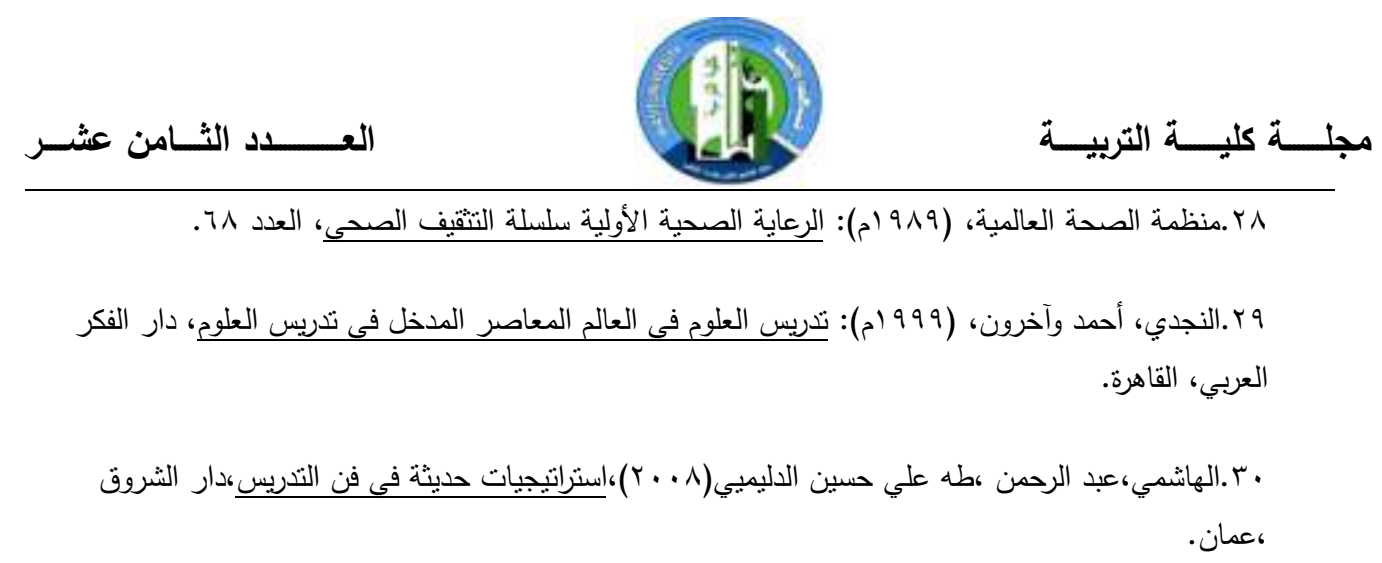

31.Bloom, B. S, Et.( 1981): Al; Evaluation to improve, Learning, New York, mc Grow Hill-book, ed.

32.Connie, P. P, (2001): Health Aware-Healthy Living, New York, The Roland press company.

33.Tonya, Gillis, (2002): Health impact Assessment-help in health-aware decisionmaking, England, Apri.

Net 1:

WWW.drmosad.com/index 79, htm, 2007

Net 2:

National Research council (NRC): National scienceeducation standards, On line Version http.www.Nap.Edu/catalog/4962-html. 